\title{
Novel insights into the interplay between peripheral reactions encoded by xyl genes and the chlorocatechol pathway encoded by tfd genes for the degradation of chlorobenzoates by Ralstonia eutropha JMP134
}

\author{
Thomas Ledger, ${ }^{1}$ Dietmar H. Pieper, ${ }^{2}$ Danilo Pérez-Pantoja ${ }^{1}$ \\ and Bernardo González ${ }^{1}$
}

1 Laboratorio de Microbiología,

Departamento de Genética Molecular y Microbiología, Facultad de Ciencias Biológicas, Pontificia Universidad Católica de Chile, Casilla 114-D Santiago, Chile

2 Division of Microbiology, National Research Centre for Biotechnology - GBF, Braunschweig, Germany Author for correspondence: Bernardo González. Tel: +56 26862845. Fax: +5622225515.
e-mail: bgonzale@genes.bio.puc.cl

\begin{abstract}
Many bacteria can grow on chloroaromatic pollutants because they can transform them into chlorocatechols, which are further degraded by enzymes of a specialized ortho-cleavage pathway. Ralstonia eutropha JMP134 is able to grow on 3-chlorobenzoate by using two pJP4-encoded, ortho-cleavage chlorocatechol degradation gene clusters $\left(t f d C_{1} D_{1} E_{1} F_{1}\right.$ and $\left.t f d D_{\| 1} C_{\|} E_{\| 1} F_{\| 1}\right)$. Very little is known about the acquisition of new catabolic genes encoding enzymes that lead to the formation of chlorocatechols in $R$. eutropha JMP134. The effect on the catabolic properties of an $R$. eutropha JMP134 derivative that received the $x y I S-x y I X Y Z L$ gene module, encoding the xyIS-regulated expression of the broad-substrate-range toluate 1,2-dioxygenase (xyIXYZ) and the 1,2-dihydro1,2-dihydroxytoluate dehydrogenase (xylL) from pWW0, which allows the transformation of 4-chlorobenzoate into 4-chlorocatechol, was studied. Such a derivative could efficiently grow on 4-chlorobenzoate. Unexpectedly, this derivative also grew on 3,5-dichlorobenzoate, a substrate for XyIXYZL but not an inducer of the XyIS regulatory protein. The ability to grow on 4chlorobenzoate or 3,5-dichlorobenzoate was also observed in derivatives of strain JMP134 containing the $x y l$ gene module but lacking $x y / S$, indicating the presence of an xylS-like element in $R$. eutropha with an inducer profile different from that of the pWW0-encoded regulator. Growth on 4chlorobenzoate was also observed after introduction of the $x y l$ gene module into strain JMP222, a JMP134 derivative lacking PJP4, but only if multiple copies of $t f d C_{1} D_{1} E_{1} F_{1}$ or $t f d D_{11} C_{11} E_{11} F_{\| 1}$ were present. However, only the derivative containing multiple copies of $t f d D_{11} C_{11} E_{11} F_{11}$ was able to grow on 3,5dichlorobenzoate. These observations indicate that although the acquisition of new catabolic genes actually enhances the catabolic abilities of $R$. eutropha JMP134, these new properties are strongly influenced by the dosage of the tfd genes, the presence of a chromosomal xylS-like regulatory element and the different contributions of the $t \mathrm{fd}$ gene clusters.
\end{abstract}

Keywords: chloroaromatic compounds, maleylacetate reductase, gene acquisition, AraC/XylS regulatory family, gene dosage

\section{INTRODUCTION}

Aerobic bacterial metabolism of chloroaromatic pollutants commonly proceeds via peripheral reactions that produce chlorocatechols, which are channelled into the central metabolism by a modified ortho-cleavage pathway (Reineke \& Knackmuss, 1988). It is assumed that the coordinated expression of peripheral reactions and

Abbreviations: $C B$, chlorobenzoate; 3-CB, 3-chlorobenzoate; 4-CB, 4-chlorobenzoate; 3,5-DCB, 3,5-dichlorobenzoate; 3-MB, 3-methylbenzoate; 4-MB, 4-methylbenzoate; 2,4-D, 2,4-dichlorophenoxyacetate. 
a
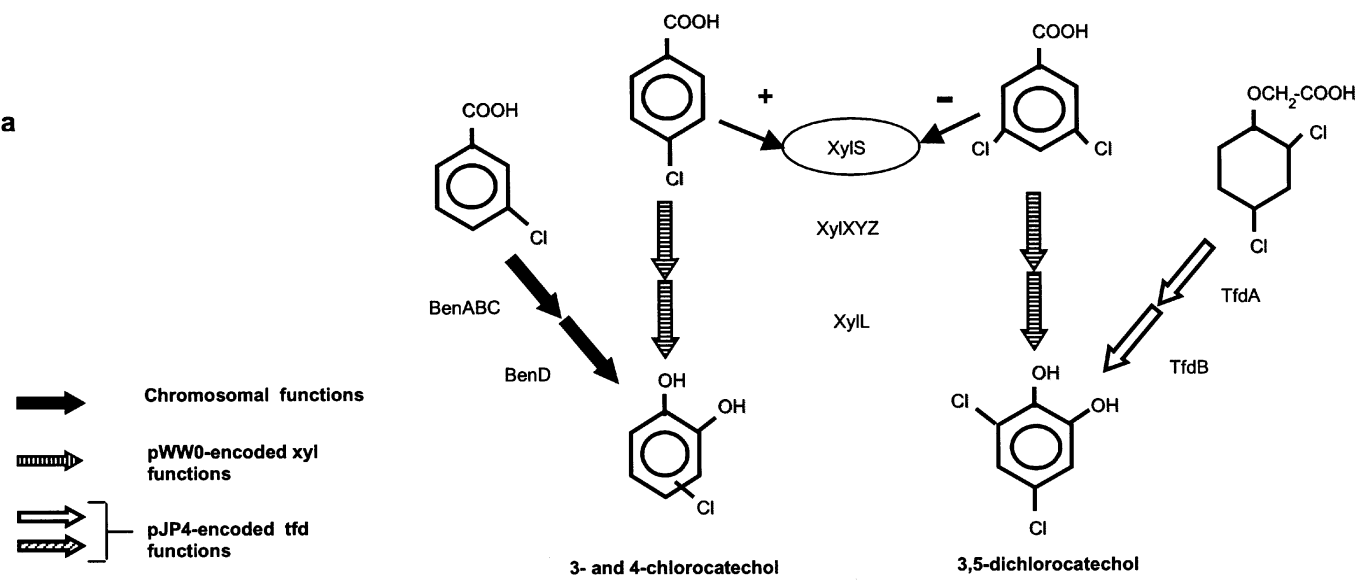

b

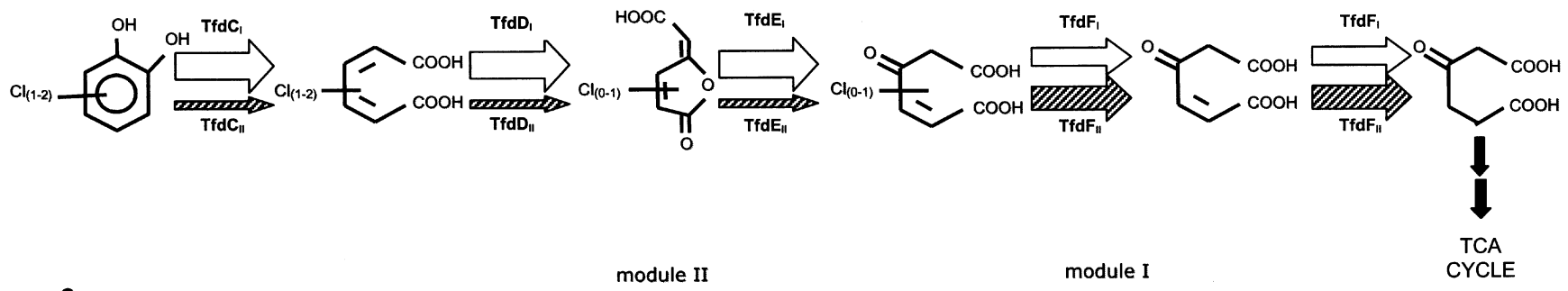

C

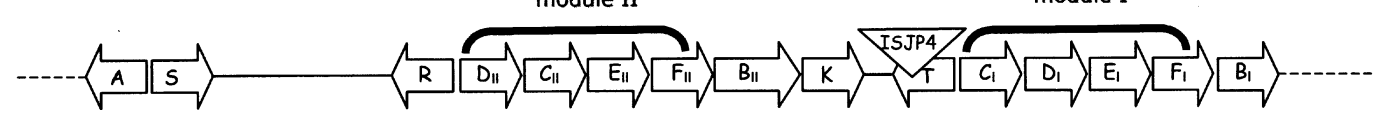

Fig. 1. $t f d$ and $x y l$ catabolic genes involved in the degradation of chloroaromatic compounds. (a) Chlorocatecholproducing peripheral reactions for 3-CB (solid arrows), 2,4-D (open arrows) or 4- and 3,5-DCB (striped arrows). $x y I X Y Z L$ encode for toluate 1,2-dioxygenase and 1,2-dihydro-1,2-dihydroxytoluate dehydrogenase, and xyls encodes for the substituted benzoate-responding transcriptional activator XylS. + And -, role as inducer or non-inducer of Xyls, respectively. (b) Modified ortho-cleavage pathway. Chlorocatechol 1,2-dioxygenase, chloromuconate cycloisomerase, dienelactone hydrolase and maleylacetate reductase catalyse the conversion of chlorocatechols to chloromuconate, to (chloro) cis-dienelactone, to (chloro) maleylacetate and to 3-oxoadipate, respectively. The different arrow widths indicate the relative specific activities of the enzymes encoded by each tfd module (Pérez-Pantoja et al., 2000; Plumeier et al., 2002). (c) Scheme for the organization of the tfd genes in pJP4, emphasizing the presence of the two tfd modules that encode for the modified ortho-cleavage pathway. Not to scale.

the chlorocatechol pathway allow bacteria to grow on chloroaromatic compounds. Therefore, it has been proposed that a wise combination of peripheral reactions with a chlorocatechol pathway should produce new or expanded catabolic properties in bacteria (Reineke, 1998). This hypothesis has been shown to be correct in several cases (e.g. Brinkmann \& Reineke, 1992; Klemba et al., 2000; Ravatn et al., 1998; Reineke \& Knackmuss, 1979, 1980; Rojo et al., 1987) and has given some insight into how a catabolic pathway may evolve in chloroaromatic-degrading bacteria.

Ralstonia eutropha JMP134 is well known for its catabolic properties toward chloroaromatic compounds. This bacterium grows on 2,4-dichlorophenoxyacetate (2,4-D) and 3-chlorobenzoate (3-CB), as well as other chloroaromatic pollutants (Clément et al., 1995 ; Don \& Pemberton, 1981; Pieper et al., 1988). The key catabolic abilities of $R$. eutropha JMP134 are encoded on the plasmid pJP4 (Don \& Pemberton, 1981), and the catabolic enzymes and genes of this plasmid have been studied extensively (Don et al., 1985; Kasberg et al., 1995; Kuhm et al., 1990; Laemmli et al., 2000; Leveau et al., 1999; Matrubutham \& Harker, 1994; Pérez-Pantoja et al., 2000; Perkins et al., 1990; Pieper et al., 1988, 1989, 1993; Seibert et al., 1993; Streber et al., 1987; Vollmer et al., 1999). Metabolism of 3-CB is initiated by the chromosomally encoded, low-specificity benzoate dioxygenase and 1,2-dihydro-1,2-dihydroxybenzene dehydrogenase to form 3-chlorocatechol and 4chlorocatechol (Fig. 1a, solid arrows). Chlorocatechol metabolism is performed by the enzymes chlorocatechol 1,2-dioxygenase, chloromuconate cycloisomerase, dienelactone hydrolase and maleylacetate reductase (Fig. $1 b$ ), encoded by $t f d C, t f d D, t f d E$ and $t f d F$, respectively, which are located in the $t f d C_{\mathrm{I}} D_{\mathrm{I}} E_{\mathrm{I}} F_{\mathrm{I}}$ and $t f d D_{\mathrm{II}} C_{\mathrm{II}} E_{\mathrm{II}} F_{\mathrm{II}}$ gene clusters of pJP4 (Fig. 1c). Neither of the $t f d$ modules is fully iso-functional, because they encode for 
enzymes whose activity profiles are different (Fig. 1b) (Laemmli et al., 2000; Pérez-Pantoja et al., 2000; Plumeier et al., 2002).

Acquisition of the full set of $t f d$-encoded genes by bacteria receiving pJP4 has been reported (Don \& Pemberton, 1981; Friedrich et al., 1983; Haugland et al., 1990; Kleinsteuber et al., 2001; Sahasrabudhe \& Modi, 1991). These studies have shown that the expression of the ability to grow on $3-\mathrm{CB}$ or $2,4-\mathrm{D}$, or on both, is strongly dependent on the recipient strain. In this context, the effect of the introduction of genes that expand the peripheral reactions already present in $R$. eutropha JMP134 has not been assessed. The interplay between new peripheral reactions with each of the two $t f d$ gene modules encoding chlorocatechol degradation in R. eutropha JMP134 is also unknown. Here we report the effect of the acquisition of catabolic genes on the ability of $R$. eutropha JMP134 and derivatives containing single or multiple copies of the $t f d C_{\mathrm{I}} D_{\mathrm{I}} E_{\mathrm{I}} F_{\mathrm{I}}$ or $t f d D_{\mathrm{II}} C_{\mathrm{II}} E_{\mathrm{II}} F_{\mathrm{II}}$ modules to grow on chlorobenzoates (CBs). For such purposes, we chose the $x y l S-x y l X Y Z L$ genes from $\mathrm{pWW0}$, a TOL (toluene degradation) plasmid, which encode the $x y l S$-regulated expression of the broad-substrate-range toluate 1,2-dioxygenase ( $x y l X Y Z)$ and the 1,2-dihydro-1,2-dihydroxytoluate dehydrogenase $(x y l L)$, which catalyse reactions for the initial metabolism of substituted benzoates (Fig. 1a, striped arrows) (Ramos et al., 1986; Reineke \& Knackmuss, 1978).

\section{METHODS}

Bacterial strains and growth conditions. The R. eutropha strains used in this work are listed in Table 1. R. eutropha JMP134 and JMP222 were grown in minimal saline medium (Kröckel \& Focht, 1987), containing $2 \mathrm{mM} 3-\mathrm{CB}$ or $1 \mathrm{mM}$ benzoate plus $1000 \mu \mathrm{g}$ streptomycin $\mathrm{ml}^{-1}$, respectively. All other R. eutropha JMP134 derivatives (Table 1) were maintained in minimal medium containing $1 \mathrm{mM}$ benzoate plus the appropriate selective antibiotic. Escherichia coli CC118ipir, E. coli HB101 and E. coli DH5 $\alpha$ derivatives harbouring the plasmids listed in Table 1 were grown in Luria-Bertani medium containing the appropriate selective antibiotic: $50 \mu \mathrm{g}$ ampicillin $\mathrm{ml}^{-1}$ or $50 \mu \mathrm{g}$ kanamycin $\mathrm{ml}^{-1} ; 20 \mu \mathrm{g}$ gentamicin $\mathrm{ml}^{-1}$ or $20 \mu \mathrm{g}$ chloramphenicol $\mathrm{ml}^{-1} ; 30 \mu \mathrm{g}$ streptomycin $\mathrm{ml}^{-1}$ or $40 \mu \mathrm{g}$ tellurite $\mathrm{ml}^{-1}$.

Growth measurements. Growth on 3-CB, 4-chlorobenzoate (4-CB), 3,5-dichlorobenzoate (3,5-DCB), 3-methylbenzoate (3-MB) or 4-methylbenzoate (4-MB) was determined by the increase in the $\mathrm{OD}_{660}$ value when measured at the stationary phase of growth, usually after $48 \mathrm{~h}$ of culture. At least three replicates for each growth measurement were carried out.

Degradation of CB by resting cells and enzyme-activity assays. For CB degradation assays, R. eutropha derivatives were grown in minimal medium containing $5 \mathrm{mM}$ fructose. At the late-exponential phase of growth, cells were induced with $3 \mathrm{mM} 4-\mathrm{CB}$ or $2 \mathrm{mM} 3,5-\mathrm{DCB}$ for at least $4 \mathrm{~h}$ or were not induced. About $100 \mathrm{ml}$ of each culture were harvested, and the resulting cell pellet was washed three times with minimal medium. The cells were then resuspended in the same medium to an $\mathrm{OD}_{660}$ value of $2 \cdot 0$, and incubated with $0.3 \mathrm{mM} 4-\mathrm{CB}$ or
3,5-DCB. The degradation of CB was monitored in a HP 8452A UV spectrophotometer (Hewlett Packard). UV spectral profiles $(210-300 \mathrm{~nm}$ ) were determined in supernatants from each sample. Under the experimental conditions used here, no spectral changes corresponding to potential metabolic products, i.e. chlorocatechols, chloromuconates or dienelactones, were observed. Abiotic controls were routinely performed by monitoring $\mathrm{CB}$ degradation in uninoculated minimalmedium-containing flasks. Degradation rates of 3,5-DCB were calculated from the absorbance decrease at $238 \mathrm{~nm}\left(\varepsilon_{238}=\right.$ $3300 \mathrm{M}^{-1} \mathrm{~cm}^{-1}$ ) after $20 \mathrm{~min}$ incubation, and are expressed in $\mu$ mol 3,5-DCB degraded $\min ^{-1}$ (mg protein $)^{-1}$. Proteins were determined by the Bradford method (Bradford, 1976), after treatment of cells with $5 \mathrm{M} \mathrm{NaOH}$ at $85^{\circ} \mathrm{C}$ for $10 \mathrm{~min}$. For activity assays of $R$. eutropha derivatives, cells were grown in $2 \mathrm{mM}$ benzoate and induced at the late-exponential phase of growth with $1 \mathrm{mM} 3-\mathrm{CB}$. Growth on benzoate and induction with 3-CB was used in these assays because not all of the $R$. eutropha derivatives grew on 3-CB. The concentration of 3$\mathrm{CB}$ used was chosen to prevent the accumulation of chlorocatechols in strains that had low levels of chlorocatechol 1,2dioxygenase. Cell extracts were obtained as follows. About $100 \mathrm{ml}$ of each culture were harvested at the end of the exponential phase of growth and centrifuged. The resulting cell pellets were washed twice and resuspended in $5 \mathrm{ml}$ of $50 \mathrm{mM}$ Tris/acetate $\left(\mathrm{pH} 7 \cdot 5\right.$ ) containing $1 \mathrm{mM} \mathrm{MnSO}_{4}$. The cells were then disrupted by sonication (Vibracell; Sonics \& Materials). The soluble protein fraction was obtained after $1 \mathrm{~h}$ centrifugation at $130000 \mathrm{~g}$, in a Beckman L-80 ultracentrifuge. Cell extracts were used without further purification. Enzyme assays for chlorocatechol 1,2-dioxygenase, maleylacetate reductase and chloromuconate cycloisomerase were performed as described previously (Pérez-Pantoja et al., 2000).

Cloning of the tfd gene modules. Restrictions, ligations, dephosphorylation reactions, DNA purification, electroporation conditions and Southern analysis were carried out following standard protocols (Ausubel et al., 1992). Different chlorocatechol catabolism $t f d$ gene modules were prepared for chromosomal insertions (using vector pUT or pBSL202) or for cloning into a medium-copy-number vector (pBBR1MCS-2). The plasmids constructed and the vectors used in this study are listed in Table 1 . The cloning of the $t f d \mathrm{R}-t f d C_{\mathrm{I}} D_{\mathrm{I}} E_{\mathrm{I}} F_{\mathrm{I}}$ gene module into the pUC18NotI derivative pUCLG2 has been described previously (Pérez-Pantoja et al., 2000). Plasmid pUCLG2 was digested with NotI and the resulting insert was introduced into pUT, to give pR1TFD. Cloning of $t f d R-$ $t f d C_{\mathrm{I}} D_{\mathrm{I}} E_{\mathrm{I}} F_{\mathrm{I}}$ into the medium-copy-number vector pBBR1MCS-2 to give pBBR1M-I has also been described previously (Pérez-Pantoja et al., 2000). To clone $t f d R-t f d D_{\mathrm{II}} C_{\mathrm{II}} E_{\mathrm{II}} F_{\mathrm{II}}$, pBSDP4 was digested with $S a c \mathrm{I} / K p n \mathrm{I}$ to generate a $5.9 \mathrm{~kb}$ fragment containing the $t f d R-t f d D_{\mathrm{II}} C_{\mathrm{II}} E_{\mathrm{II}} F_{\mathrm{II}}$ gene module; this fragment was then introduced into pHRP316 to give pHRPMII. pHRP316 was only used for intermediate cloning steps. The $6 \mathrm{~kb}$ HindIII fragment of pHRPM-II was cloned into pBBR1MCS-2 to yield pBBRHM-II. The $t f d$ gene module was extracted from pBBRHM-II with a SpeI digestion, and then introduced into pBSL202 to give pR2TFDG. Additionally, the SpeI fragment from pBBRHM-II was introduced into pR1TFDG, a pBSL202 derivative in which a $5.1 \mathrm{~kb}$ NotI fragment from pUCLG 2 containing the $t f d R-t f d C_{\mathrm{I}} D_{\mathrm{I}} E_{\mathrm{I}} F_{\mathrm{I}}$ gene module had been cloned previously, to produce pR12TFDG. The latter contains tandem, direct copies of each $t f d$ module. Cloning of $t f d R-t f d D_{\mathrm{II}} C_{\mathrm{II}} E_{\mathrm{II}} F_{\mathrm{II}}$ into pBBR1MCS-2, to give pBBR1M-II, has been described previously (Pérez-Pantoja et al., 2000). The maleylacetate reductase gene encoded on pBBR1M-I was inactivated by a $0.6 \mathrm{~kb}$ deletion corresponding 
Table 1. Strains and plasmids used in this study

\begin{tabular}{|c|c|c|}
\hline Strain/plasmid & Relevant phenotype/genotype* & Source/reference $†$ \\
\hline \multicolumn{3}{|l|}{ R. eutropha } \\
\hline JMP134 & $2,4-\mathrm{D}, 3-\mathrm{CB}$ & DSMZ \\
\hline JMP134::X & 2,4-D, 3-CB, 4-CB, 3,5-DCB, 3-MB, 4-MB; $x y l S-x y l X Y Z L$ & This work \\
\hline JMP134::X $\Delta$ S & 2,4-D, 3-CB, 4-CB, 3,5-DCB, 3-MB, 4-MB; $x y l X Y Z L$ & This work \\
\hline $\mathrm{JMP} 134:: \mathrm{X}\left(\mathrm{pJP} 4 \Delta \mathrm{F}_{\mathrm{II}}\right)$ & 3-CB, 4-CB, 3-MB, 4-MB; $x y l S-x y l X Y Z L$ & This work \\
\hline JMP222 & $\mathrm{Sm}^{\mathrm{r}}$; a pJP4-cured JMP134 derivative & Don \& Pemberton (1981) \\
\hline JMP222:: X & $\mathrm{Sm}^{\mathrm{r}} ; x y l S-x y l X Y Z L$ & This work \\
\hline JMP222: : R1TFD & $\mathrm{Sm}^{\mathrm{r}} ; t f d R-t f d C_{\mathrm{I}} D_{\mathrm{I}} E_{\mathrm{I}} F_{\mathrm{I}}$ & This work \\
\hline JMP222:: R2TFD & $\mathrm{Sm}^{\mathrm{r}} ; t f d R-t f d D_{\mathrm{II}} C_{\mathrm{II}} E_{\mathrm{II}} F_{\mathrm{II}}$ & This work \\
\hline JMP222::R12TFD & $S \mathrm{~m}^{\mathrm{r}} ; t f d R-t f d C_{\mathrm{I}} D_{\mathrm{I}} E_{\mathrm{I}} F_{\mathrm{I}}, t f d R-t f d D_{\mathrm{II}} C_{\mathrm{II}} E_{\mathrm{II}} F_{\mathrm{II}}$ & This work \\
\hline JMP222:: X::R1TFD & $\mathrm{Sm}^{\mathrm{r}}, \mathrm{Te}^{\mathrm{r}} ; x y l S-x y l X Y Z L, t f d R-t f d C_{\mathrm{I}} D_{\mathrm{I}} E_{\mathrm{I}} F_{\mathrm{I}}$ & This work \\
\hline JMP222::X::R2TFD & $\mathrm{Sm}^{\mathrm{r}}, \mathrm{Te}^{\mathrm{r}} ; x y l S-x y l X Y Z L, t f d R-t f d D_{\mathrm{II}} C_{\mathrm{II}} E_{\mathrm{II}} F_{\mathrm{II}}$ & This work \\
\hline JMP222::X::R12TFD & $\mathrm{Sm}^{\mathrm{r}}, \mathrm{Te}^{\mathrm{r}} ; x y l S-x y l X Y Z L t f d R-t f d C_{\mathrm{I}} D_{\mathrm{I}} E_{\mathrm{I}} F_{\mathrm{I}}, t f d R-t f d D_{\mathrm{II}} C_{\mathrm{II}} E_{\mathrm{II}} F_{\mathrm{II}}$ & This work \\
\hline JMP222::X(pBBR1M-I) & $3-\mathrm{CB}, 4-\mathrm{CB} ; \mathrm{Sm}^{\mathrm{r}}, \mathrm{Te}^{\mathrm{r}}, \mathrm{Km}^{\mathrm{r}} ; x y l S-x y l X Y Z L t f d R-t f d C_{\mathrm{I}} D_{\mathrm{I}} E_{\mathrm{I}} F_{\mathrm{I}}$ & This work \\
\hline JMP222::X(pBBR1M-II) & $\begin{array}{l}\text { 3-CB, 4-CB, 3,5-DCB; } \mathrm{Sm}^{\mathrm{r}}, \mathrm{Te}^{\mathrm{r}}, \mathrm{Km}^{\mathrm{r}} ; x y l S-x y l X Y Z L \\
t f d R-t f d D_{\mathrm{II}} C_{\mathrm{II}} E_{\mathrm{II}} F_{\mathrm{II}}\end{array}$ & This work \\
\hline $\mathrm{JMP} 222: \mathrm{X}\left(\mathrm{pBBR} \Delta \mathrm{F}_{\mathrm{I}}\right)$ & $3-\mathrm{CB}, 4-\mathrm{CB} ; \mathrm{Sm}^{\mathrm{r}}, \mathrm{Te}^{\mathrm{r}}, \mathrm{Km}^{\mathrm{r}} ; x y l S-x y l X Y Z L, t f d R-t f d C_{\mathrm{I}} D_{\mathrm{I}} E_{\mathrm{I}}$ & This work \\
\hline $\mathrm{JMP} 222:: \mathrm{X}\left(\mathrm{pBBR} \Delta \mathrm{F}_{\mathrm{II}}\right)$ & $3-\mathrm{CB}, 4-\mathrm{CB}, \mathrm{Sm}^{\mathrm{r}}, \mathrm{Te}^{\mathrm{r}}, \mathrm{Km}^{\mathrm{r}} ; x y l S-x y l X Y Z L, t f d R-t f d D_{\mathrm{II}} C_{\mathrm{II}} E_{\mathrm{II}}$ & This work \\
\hline \multicolumn{3}{|l|}{ Plasmid } \\
\hline pRK600 & $\mathrm{Cm}^{\mathrm{r}} ; \operatorname{tra}^{+}$ & de Lorenzo et al. (1990) \\
\hline pBSL202 & $\mathrm{Gm}^{\mathrm{r}}, \mathrm{Ap}^{\mathrm{r}}$ & Alexeyev et al. (1995) \\
\hline pHRP316 & $\mathrm{Sm} / S \mathrm{p}^{\mathrm{r}}, A \mathrm{p}^{\mathrm{r}}$ & Parales \& Harwood (1993) \\
\hline pBBR1MCS-2 & $\mathrm{Km}^{\mathrm{r}}$; broad-host-range & Kovach et al. (1995) \\
\hline pUT & $\mathrm{Km}^{\mathrm{r}}, \mathrm{Ap}^{\mathrm{r}}$ & de Lorenzo et al. (1990) \\
\hline pSPM100 & $\mathrm{Ap}^{\mathrm{r}}, \mathrm{Te}^{\mathrm{r}} ; x y l S-x y l X Y Z L, \mathrm{pUT}$ derivative & V. de Lorenzo \\
\hline pUCLG2 & $A p^{r} ; t f d R-t f d C_{\mathrm{I}} D_{\mathrm{I}} E_{\mathrm{I}} F_{\mathrm{I}}, \mathrm{pUC18NotI}$ derivative & Pérez-Pantoja et al. (2000) \\
\hline pBSDP4 & $\mathrm{Ap}^{\mathrm{r}} ; t f d R-t f d D_{\mathrm{II}} C_{\mathrm{II}} E_{\mathrm{II}} F_{\mathrm{II}}$, pBSKSII derivative & Pérez-Pantoja et al. (2000) \\
\hline $\mathrm{pSPM} \Delta \mathrm{S}$ & $\mathrm{Ap}^{\mathrm{r}}, \mathrm{Te}^{\mathrm{r}} ; x y l X Y Z L$, pUT derivative & This work \\
\hline pR1TFD & $\mathrm{Km}^{\mathrm{r}}, \mathrm{Ap}^{\mathrm{r}} ; t f d R-t f d C_{\mathrm{I}} D_{\mathrm{I}} E_{\mathrm{I}} F_{\mathrm{I}}, \mathrm{pUT}$ derivative & This work \\
\hline pR1TFDG & $\mathrm{Gm}^{\mathrm{r}}, A \mathrm{p}^{\mathrm{r}} ; t f d R-t f d C_{\mathrm{I}} D_{\mathrm{I}} E_{\mathrm{I}} F_{\mathrm{I}}, \mathrm{pBSL} 202$ derivative & This work \\
\hline pR2TFDG & $\mathrm{Gm}^{\mathrm{r}}, \mathrm{Ap}^{\mathrm{r}} ; t f d R-t f d D_{\mathrm{II}} C_{\mathrm{II}} E_{\mathrm{II}} F_{\mathrm{II}}, \mathrm{pBSL} 202$ derivative & This work \\
\hline pR12TFDG & $\mathrm{Gm}^{\mathrm{r}}, \mathrm{Ap}^{\mathrm{r}} ; t f d R-t f d D_{\mathrm{II}} C_{\mathrm{II}} E_{\mathrm{II}} F_{\mathrm{II}}, t f d R-t f d C_{\mathrm{I}} D_{\mathrm{I}} E_{\mathrm{I}} F_{\mathrm{I}}$, pBSL202 derivative & This work \\
\hline pBBRHM-II & $\mathrm{Km}^{\mathrm{r}} ; t f d R-t f d D_{\mathrm{II}} C_{\mathrm{II}} E_{\mathrm{II}} F_{\mathrm{II}}$, pBBR1MCS-2 derivative & This work \\
\hline pHRPM-II & $\mathrm{Sm} / \mathrm{Sp}^{\mathrm{r}}, A \mathrm{p}^{\mathrm{r}} ; t f d R-t f d D_{\mathrm{II}} C_{\mathrm{II}} E_{\mathrm{II}} F_{\mathrm{II}}, \mathrm{pHRP} 316$ derivative & This work \\
\hline pBBR1M-I & $\mathrm{Km}^{\mathrm{r}} ; t f d R-t f d C_{\mathrm{I}} D_{\mathrm{I}} E_{\mathrm{I}} F_{\mathrm{I}}, \mathrm{pBBR} 1 \mathrm{MCS}-2$ derivative & Pérez-Pantoja et al. (2000) \\
\hline pBBR1M-II & $\mathrm{Km}^{\mathrm{r}} ; t f d R-t f d D_{\mathrm{II}} C_{\mathrm{II}} E_{\mathrm{II}} F_{\mathrm{II}}$, pBBR1MCS-2 derivative & Pérez-Pantoja et al. (2000) \\
\hline $\mathrm{pBBR} 1 \Delta \mathrm{F}_{\mathrm{I}}$ & $\mathrm{Km}^{\mathrm{r}} ; t f d R-t f d C_{\mathrm{I}} D_{\mathrm{I}} E_{\mathrm{I}}, \mathrm{pBBR} 1 \mathrm{MCS}-2$ derivative & This work \\
\hline $\mathrm{pBBR} 1 \Delta \mathrm{F}_{\mathrm{II}}$ & $\mathrm{Km}^{\mathrm{r}} ; t f d R-t f d D_{\mathrm{II}} C_{\mathrm{II}} E_{\mathrm{II}}$, pBBR1MCS-2 derivative & This work \\
\hline
\end{tabular}

*Able to grow on the chloro and methyl aromatic compounds shown. Ap ${ }^{\mathrm{r}}$, ampicillin-resistant; Km ${ }^{\mathrm{r}}$, kanamycin-resistant; Cm ${ }^{\mathrm{r}}$, chloramphenicol-resistant; $\mathrm{Sm}^{\mathrm{r}}$, streptomycin-resistant; $\mathrm{Sp}^{\mathrm{r}}$, spectinomycin-resistant; $\mathrm{Gm}^{\mathrm{r}}$, gentamicin-resistant; Te${ }^{\mathrm{r}}$, tellurite-resistant; tra, transfer functions.

†DSMZ, Deutsche Sammlung von Mikroorganismen und Zellkulturen, Braunschweig, Germany.

to the internal AatII sites in the $t f d F_{\mathrm{I}}$ gene, to produce $\mathrm{pBBR} \Delta \mathrm{F}_{\mathrm{I}}$. To construct a pBBR1M-II derivative lacking the maleylacetate reductase gene, the $8.3 \mathrm{~kb}$ EcoRI fragment of pJP4 was cloned in pUC18NotI, and its $4.5 \mathrm{~kb}$ SacI fragment containing the $t f d R-t f d D_{\mathrm{II}} C_{\mathrm{II}} E_{\mathrm{II}}$ genes was directly cloned into $\mathrm{pBBR} 1 \mathrm{MCS}-2$, to give $\mathrm{pBBR} \Delta \mathrm{F}_{\mathrm{II}}$. A 10 -fold decrease in maleylacetate reductase activity was determined for strain JMP222 $\left(\mathrm{pBBR} \Delta \mathrm{F}_{\mathrm{II}}\right)$ with respect to strain JMP222(pBBR1MII). The determination of this activity in strain JMP222 $\left(\mathrm{pBBR} \Delta \mathrm{F}_{\mathrm{I}}\right)$ was not performed because JMP222(pBBR1M-I) has a maleylacetate reductase activity level similar to that found in the chromosome of strain JMP222 (Pérez-Pantoja et al., 2000).
Construction of a $x y I X Y Z L$ gene module. A pUT derivative, pSPM100, containing the $x y l S-x y l X Y Z L$ gene module of the TOL plasmid pWW0 and resistance to tellurite as a selective marker was obtained from V. de Lorenzo (S. Panke \& V. de Lorenzo, unpublished data). To construct an unregulated $x y l$ gene module, pSPM100 was digested with BstEII, which produces three cuts in this plasmid, to remove a $725 \mathrm{bp}$ internal $x y l S$ fragment that included the translation initiation site of the gene. The remaining two fragments of pSPM100 were re-ligated in the proper orientation and designated as $\mathrm{pSPM} \Delta \mathrm{S}$. The BstEII and NotI restriction profiles of pSPM $\Delta \mathrm{S}$ were determined and were in agreement with the deletion of the internal $x y l S$ fragment. The absence or presence of an 
active XylS regulatory protein was verified in E. coli cells containing $\mathrm{pSPM} \Delta \mathrm{S}$ or $\mathrm{pSPM} 100$, respectively, by visual detection of the production of an intense brown colour due to chlorocatechol accumulation when these cells were exposed to 3-CB.

Introduction of the tfd and/or $x y l$ gene modules into $\boldsymbol{R}$. eutropha. The introduction of the $t f d$ and/or $x y l$ gene modules was performed by using mini-Tn5-derived vectors (de Lorenzo et al., 1990) or pBBR1MCS-2, which were transferred by triparental mating with E. coli CC118ipir containing pBBR1MCS-2 (pBBR1M-I, pBBR1M-II), pUT (pR1TFD, pSPM100, pSPM $\Delta$ S) or pBSL202 (pR2TFDG, pR12TFDG) derivatives as donors (Table 1), E. coli HB101(pRK600) as the helper and $R$. eutropha JMP134 or JMP222, or derivatives thereof, as recipients. A donor-to-helper-to-recipient ratio of $1: 1: 2$ was used. After incubation, cells were resuspended and the transconjugants were selected on agar plates containing minimal medium supplemented with $3 \mathrm{mM}$ benzoate plus $50 \mu \mathrm{g}$ kanamycin $\mathrm{ml}^{-1}$ (pUT and pBBR1MCS-2 derivatives), $3 \mathrm{mM}$ benzoate plus $20 \mu \mathrm{g}$ gentamicin $\mathrm{ml}^{-1}$ (pBSL202 derivatives) or $2 \mathrm{mM} 2,4-\mathrm{D}$ plus $40 \mu \mathrm{g}$ tellurite $\mathrm{ml}^{-1}$ (pSPM100 derivatives). Six to ten derivatives from each mating were analysed for the absence of plasmid DNA, ampicillin sensitivity and stable maintenance ( 20 generations) of kanamycin, gentamicin or tellurite resistance after growth in Luria-Bertani medium without a selective marker. To detect the tnp Tn5 IS50R transposase gene, primer pair TNP-1 (5'-CGGCGGCGCTGGGTGATCCT-3') and TNP-2 (5'-GCCCCAGCTGGCAATTCCGG-3') (nucleotides 148-167 and 1414-1433, respectively, of GenBank accession no. U15573) was used (Ahmed \& Podemski, 1995). Failure to detect this gene was an indication that the vector had been lost and that transposition had occurred (de Lorenzo et al., 1990). The absence of tnp, sensitivity to ampicillin, stable inheritance of kanamycin, gentamicin or tellurite resistance and the absence of the corresponding plasmid indicated that insertion of cloned genes had occurred. Southern analysis with a biotinylated pR1TFD, pR2TFDG or pSPM100 DNA probe was carried out to confirm that the selected derivatives carried single insertions of the corresponding $t f d$ or $x y l$ gene module. All transconjugants showed single insertions of the $t f d$ or $x y l$ genes, as determined by Southern hybridization, indicating successful establishment of the genes in the transconjugants. Southern analysis performed with a pSPM100 probe showed the presence of single insertions of the $x y l$ genes, into either the chromosome or pJP4. To confirm the presence of the chlorocatechol genes in the transconjugants, PCR was performed using the primer pair BDO-1 and VAL-2 (PérezPantoja et al., 2000) to amplify a $1.8 \mathrm{~kb} t f d C_{\mathrm{I}} D_{\mathrm{I}}$ fragment. The primer pair RBA-1 (5'-CAACGAAATAGCGAAGCTGTCGA-3') and RDB-1 (5'-ATGAGCACGCTGCTCTGATGCTTG-3') (nucleotides 863-885 and 1141-1164, respectively, of GenBank accession no. M98445) was used to amplify a $302 \mathrm{bp}$ fragment of the $t f d R-t f d D_{\mathrm{II}}$ intergenic region. Conditions for PCR were: denaturation at $95^{\circ} \mathrm{C}$ for $2 \mathrm{~min}$, followed by 35 cycles at $95^{\circ} \mathrm{C}$ for $45 \mathrm{~s}, 55^{\circ} \mathrm{C}$ for $30 \mathrm{~s}$ and $72{ }^{\circ} \mathrm{C}$ for $30 \mathrm{~s}$, with a final extension at $72{ }^{\circ} \mathrm{C}$ for $10 \mathrm{~min}$.

Detection of a xylS gene homologue in $R$. eutropha. Southern hybridization of $R$. eutropha JMP134 genomic DNA that had been digested with EcoRI was performed using the $725 \mathrm{bp}$ $B s t$ EII-generated fragment from $x y l S$ as a biotinylated probe. A $684 \mathrm{bp}$ region from an ORF taken from the genomic sequence of Ralstonia metallidurans $\mathrm{CH} 34$, encoding a $x y l S$ gene homologue, was amplified by PCR using primers FOR 130 (5'-TCCTTCAACCGGCTCAGTTA-3') and REV814 (5'ATGCGTCATTGAGCAGATCC-3'). $R$. metallidurans
$\mathrm{CH} 34$ is a strain closely related to R. eutropha JMP134, whose genome sequence is available at the Department of Energy (DOE) Joint Genome Institute (http://www.jgi.doe.gov/ JGI_microbial/html/). Conditions for PCR were: denaturation at $94{ }^{\circ} \mathrm{C}$ for $5 \mathrm{~min}$, followed by 28 cycles at $94{ }^{\circ} \mathrm{C}$ for $30 \mathrm{~s}$, $55^{\circ} \mathrm{C}$ for $1 \mathrm{~min}$ and $72^{\circ} \mathrm{C}$ for $90 \mathrm{~s}$, with a final extension at $72{ }^{\circ} \mathrm{C}$ for $10 \mathrm{~min}$. The resulting PCR product was also used as a probe for the R. eutropha JMP134 genomic DNA that had been digested with EcoRI.

Construction of an $R$. eutropha JMP134 derivative harbouring a $t \boldsymbol{f d} \boldsymbol{F}_{\mathrm{II}}$-inactivated $\mathbf{p J P 4}$. To inactivate the $t f d F_{\mathrm{II}}$ gene in $\mathrm{pJP} 4$, the $1.0 \mathrm{~kb}$ pBSL202 fragment encoding gentamicin resistance was introduced into the $M l u \mathrm{I}$ sites of the $1.0 \mathrm{~kb}$ EcoRI-NdeI fragment from the $t f d F_{\mathrm{II}}$ gene, and the resulting fragment was cloned into pLITMUS. The resulting plasmid was introduced into R. eutropha JMP134 by electroporation; homologous recombination derivatives were selected on the basis of a gentamicin-resistant, ampicillin-sensitive phenotype. The insertion in the $t f d F_{\mathrm{II}}$ gene was verified by Southern analysis of plasmid DNA that had been digested with EcoRI, which showed positive hybridization with the gentamicin-resistance probe only in the $\mathrm{pJP} 4$ derivative $\left(\mathrm{pJP} 4 \Delta \mathrm{F}_{\mathrm{II}}\right)$ DNA fragment that had altered mobility with respect to the wild-type pJP4 DNA. A sevenfold decrease in maleylacetate reductase activity was found in strain JMP134 $\left(\mathrm{pJP} 4 \Delta \mathrm{F}_{\mathrm{II}}\right)$, when compared to the wild-type strain.

\section{RESULTS AND DISCUSSION}

\section{Growth of $R$. eutropha JMP134 on CBs after acquisition of the pWW0-derived $x y I S-x y I X Y Z L$ gene module}

R. eutropha JMP134 does not grow on 4-CB. This may be due to the narrow substrate range of its benzoate 1,2dioxygenase, which would only transform benzoate and 3-CB at significant rates, as has been reported for the closely related strain B9, a mutant of strain 335, the type strain of $R$. eutropha (formerly Alcaligenes eutrophus) (Reineke \& Knackmuss, 1978). We determined whether the acquisition of the broad-substraterange enzyme toluate (methylbenzoate) 1,2-dioxygenase ( $x y l X Y Z$ ) and the 1,2-dihydro-1,2-dihydroxytoluate dehydrogenase $(x y l L)$, regulated by their transcriptional activator $x y l S$ and, therefore, providing a better peripheral function for CB degradation, can actually expand the growth substrate range of strain JMP134. The $\mathrm{pWW0}$-encoded enzymes can efficiently transform alkyl-substituted benzoates such as $3-\mathrm{MB}$ and $4-\mathrm{MB}$, as well as chlorinated compounds such as $3-\mathrm{CB}, 4-\mathrm{CB}$ and 3,5-DCB, to their corresponding catechols (Reineke \& Knackmuss, 1978), although 3,5-DCB is not an inducer of XylS (Ramos et al., 1986). The $x y l S-x y l X Y Z L$ genes were introduced into R. eutropha JMP134 and JMP222 using mini-Tn5-derived vectors. All of the derivatives of $R$. eutropha JMP134 containing the $x y l S-x y l X Y Z L$ genes inserted into the chromosome, or into pJP4 $(R$. eutropha JMP134::X), could grow on $0.5-10 \mathrm{mM} 4-\mathrm{CB}$ (Fig. 2a) and on $2 \mathrm{mM} 3-\mathrm{MB}$ or 4-MB (not shown). Unexpectedly, the presence of $x y l S-x y l X Y Z L$ also allowed growth of all of these derivatives on $0.5-10 \mathrm{mM}$ 3,5-DCB (Fig. 2b), a substrate of the toluate dioxygenase system but not an inducer of the XylS regulator. Control growth tests for the wild-type strain JMP134, performed 

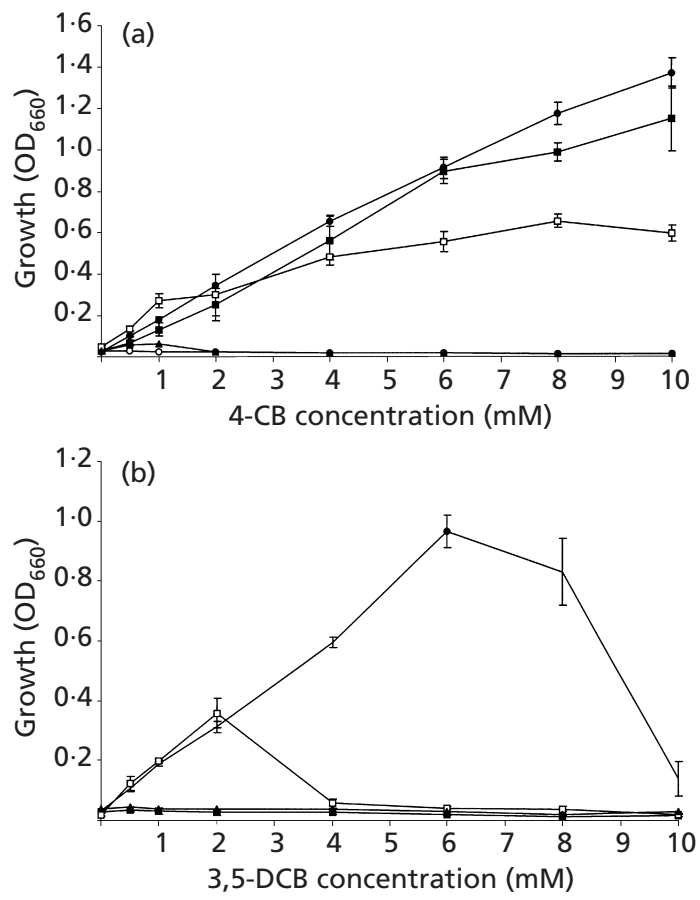

Fig. 2. Growth of $R$. eutropha derivatives containing the $x y l$ and $t f d$ gene modules on CBs. Effects of the CB concentration on growth with (a) 4-CB or (b) 3,5-DCB of $R$. eutropha JMP134 and its derivative containing the $x y / S-x y I X Y Z L$ genes, namely JMP134::X and derivatives of strain JMP222(pBBR1M-I), JMP222(pBBR1M-II) and JMP222::R1TFD. Samples were taken at the stationary phase of growth, usually after $48 \mathrm{~h}$ cultivation. Each point corresponds to the mean $\pm S D$ of three independent experiments. In (a) and (b): O, JMP134::X(pJP4); O, JMP134(pJP4); $\mathbf{\square}, J M P 222:: X(p B B R 1 M-I) ; \square, J M P 222:: X(p B B R 1 M-I I) ;$ $\boldsymbol{\Delta}$, JMP222::X::R1TFD.

on plates containing 4-CB or 3,5-DCB, were negative, indicating that these new catabolic abilities are not due to spontaneous mutations, but to the presence of the $x y l$ genes plus the $t f d$ genes. Accordingly, the introduction of the $x y$ l genes into strain JMP222, which lacked the $t f d$ genes, did not enable cells to grow on 4-MB, 4-CB or 3,5DCB, even after more than 15 days incubation, but it did permit growth on $3-\mathrm{MB}$, because this compound is mainly transformed to 3-methylcatechol. A chromosomal meta-ring-cleavage pathway (Pieper et al., 1988) can subsequently metabolize this catechol.

The transfer of $\mathrm{pWW} 0$ to Pseudomonas sp. B13, another chlorocatechol-degrading bacterium, has been described, and allows transconjugants to grow on 4-CB and 3,5-DCB (Reineke \& Knackmuss, 1979). However, these transconjugants were obtained at low frequencies $\left(10^{-8}\right.$ transconjugants per donor cell, or spontaneous mutation frequency) by direct plating onto each $\mathrm{CB}$, selecting for mutations in addition to the transference of the $x y l$ genes. This is not the case for R. eutropha containing the $x y l$ genes, because the initial selection of transconjugants was performed in 2,4-D plus tellurite and, therefore, did not select for mutations involved in CB-degrading abilities.
Table 2. Relative rates of 3,5-DCB degradation by derivatives of $R$. eutropha JMP134

Cells were grown on fructose, exposed or not to 4-CB or 3,5$\mathrm{DCB}$, and degradation rates of $\mathrm{CB}$ as substrate were measured. Only results using 3,5-DCB as substrate are shown, because no significant differences in degradation were found using 4-CB or 3,5-DCB as substrates. Relative degradation rates were calculated with respect to strain JMP134:: X, which was induced with 4-CB. The absolute degradation rate for this strain/condition was $39 \mu \mathrm{mol} 3,5$-DCB degraded $\mathrm{min}^{-1}$ (mg protein $)^{-1}$. Results for three separate experiments are shown as the mean $\pm S D$.

\begin{tabular}{|lccc|}
\hline R. eutropha strain & \multicolumn{3}{c|}{ Inducer } \\
\cline { 2 - 4 } & None & 4-CB & 3,5-DCB \\
\hline JMP134::X & $3 \pm 1$ & $100 \pm 12$ & $57 \pm 11$ \\
JMP134::X $\Delta S$ & $3 \pm 1$ & $90 \pm 3$ & $75 \pm 3$ \\
JMP134 & $3 \pm 1$ & $5 \pm 1$ & $3 \pm 1$ \\
JMP222::X & $1 \pm 1$ & $89 \pm 3$ & $61 \pm 7$ \\
\hline
\end{tabular}

\section{Evidence for the presence of a putative AraC/XylS family regulator capable of activating $x y l$ gene expression in $R$. eutropha JMP134}

The ability of R. eutropha JMP134:: X to grow on 3,5DCB suggests that this compound acts as an inducer with the XylS regulatory protein and/or that another regulatory system present in R. eutropha replaces XylS, activating transcription of the $x y l$ operon. The first possibility does not seem correct, because it has been reported that 3,5-DCB is unable to activate the regulator in Pseudomonas putida (Ramos et al., 1986). Furthermore, 3,5-DCB can also act as an inhibitor of the XylSmediated induction of the $x y l X Y Z L$ genes in the presence of other substituted benzoates (Ramos et al., 1986). To test the second possibility (i.e. that another regulatory system replaces XylS), we constructed a pSPM100 derivative that has a $0.7 \mathrm{~kb}$ deletion in $x y l S$ and, therefore, lacks the possibility of induction mediated by this regulator. When the $x y l X Y Z L$ gene module was introduced into R. eutropha JMP134, the resulting derivative, R. eutropha JMP134::X $\Delta \mathrm{S}$, was still able to grow on 4-CB and 3,5-DCB to the same extent as the strain harbouring the complete $x y l$ gene module. The degradation of CBs in R. eutropha JMP134 derivatives containing or lacking $x y l S$ (strains JMP134::X and JMP134::X $\Delta$ S, respectively) was studied in cells grown on fructose and induced with 4-CB or 3,5-DCB (Table 2). The results showed that XylXYZ activity in these derivatives is due to the acquisition of the $x y l$ genes, because only negligible activity was observed in the wild-type strain. The results also show that XylXYZ activity is inducible by $4-\mathrm{CB}$ or $3,5-\mathrm{DCB}$ and, more significantly, that XylS was not required for such an induction, indicating the presence of another regulatory system in $R$. eutropha JMP134. When the rate of CB degradation was determined for R. eutropha JMP222 harbouring the $x y l S-x y l X Y Z L$ module $(R$. eutropha 
JMP222::X), essentially the same pattern of degradation was found (Table 2), indicating that the activity of a putative XylS element in R. eutropha is located in the chromosome and is not part of the pJP4-encoded genes. Therefore, it is possible that in the chromosome of strain JMP134 a regulatory function is responding to $\mathrm{CBs}$ and is cross-activating the expression of the $x y l X Y Z L$ module. This kind of cross-regulation has been shown in $P$. putida for benzoate catabolism, between the pWW0-encoded proteins XylS and BenR, the regulator of the chromosomal benzoate-degradation pathway and both proteins belonging to the AraC/XylS family of regulators (Cowles et al., 2000; Jeffrey et al., 1992). To obtain further evidence for the presence of a putative AraC/XylS family regulator similar to XylS from pWW0 in the chromosome of $R$. eutropha, Southern hybridization of EcoRI-digested JMP134 and JMP222 genomic DNA was performed using the $725 \mathrm{bp}$ BstEII-generated fragment containing part of $x y l S$. No hybridization signal was observed for either derivative, even under low-stringency conditions. Nevertheless, the use of the 684 bp PCR product from a $x y l S$ homologue of $R$. metallidurans $\mathrm{CH} 34$ as a probe revealed a single hybridization band of approximately $4 \mathrm{~kb}$ in size in both the R. eutropha JMP134 and the JMP222 genomic DNA that had been digested with EcoRI. It is worth mentioning that the putative protein found in the $R$. metallidurans genome has only $24 \%$ nucleotide identity ( $30 \%$ amino-acid identity) with $x y l S$ from $\mathrm{pWW0.} \mathrm{If} \mathrm{it}$ is assumed that the gene from R. eutropha JMP134 is closely related to that of $R$. metallidurans, such low identity would explain the failure to find the $x y l S$ sequence in the R. eutropha genome when using $x y l S$ from pWW0 as the probe. Taken together, these results strongly suggest that the chromosome of strain JMP134 has a BenR/XylS-like element with an inducer profile different to that reported for XylS from pWW0.

\section{Growth of $R$. eutropha JMP222 derivatives harbouring the $x y I S-x y I X Y Z L$ gene module on CBs requires the presence of multiple copies of the $t f d C_{1} D_{1} E_{1} F_{1}$ or $t f d D_{\| 1} C_{\|} E_{\| I} F_{\|}$gene modules}

Plasmid pJP4 possesses an uncommon catabolic gene organization (van der Meer et al., 1992), with two different, but almost iso-functional, gene modules encoding chlorocatechol degradation (Leveau et al., 1999). We determined whether each of the $t f d$ gene modules was enough to allow growth on CBs when expressed separately in strain JMP222 harbouring the $x y l$ genes. First, $t f d R-t f d C_{\mathrm{I}} D_{\mathrm{I}} E_{\mathrm{I}} F_{\mathrm{I}}, t f d R-t f d D_{\mathrm{II}} C_{\mathrm{II}} E_{\mathrm{II}} F_{\mathrm{II}}$ or both gene modules were introduced into strain JMP222 by using mini-Tn5-derived vectors (these vectors produced single copies of each gene module). When the derivatives R. eutropha JMP222::R1TFD, JMP222::R2TFD and JMP222::R12TFD (Table 1), respectively, were used as recipients for the $x y l S-x y l X Y Z L$ genes, the resulting transconjugants $[R$. eutropha JMP222::X::R1TFD, JMP222::X::R2TFD and JMP222::X::R12TFD (Table 1), respectively] were unable to grow on $0 \cdot 5-$ $10 \mathrm{mM}$ 4-CB or 3,5-DCB (Fig. 2a, b; only
Table 3. Specific activities of chlorocatechol 1,2dioxygenase (TfdC) in crude extracts of derivatives of $R$. eutropha JMP134 harbouring chromosomal insertions of the $t f d$ and $x y l$ genes

Cells were grown on benzoate and induced for $4 \mathrm{~h}$ with $1 \mathrm{mM}$ 3-CB. Only results using 3,5-dichlorocatechol as substrate are shown. Results for three separate experiments are shown as the mean \pm SD.

\begin{tabular}{|lc|}
\hline R. eutropha strain & $\begin{array}{c}\text { TfdC activity } \\
{\left[\mathrm{U}(\mathbf{m g} \text { protein })^{-1}\right]}\end{array}$ \\
\hline JMP134::X & $0 \cdot 24 \pm 0 \cdot 01$ \\
JMP222:: X & $<0 \cdot 02$ \\
JMP222::R1TFD $:: \mathrm{X}$ & $0 \cdot 05 \pm 0 \cdot 01$ \\
JMP222::R2TFD $:: \mathrm{X}$ & $0 \cdot 02 \pm 0 \cdot 01$ \\
JMP222::R12TFD $:: \mathrm{X}$ & $0 \cdot 07 \pm 0 \cdot 02$ \\
\hline
\end{tabular}

JMP222::X::R1TFD is shown). These derivatives were also unable to grow in liquid cultures containing $0 \cdot 5-10 \mathrm{mM} 3-\mathrm{CB}$. An effect on expression due to the chromosomal position of the introduced genes can be disregarded, because the derivatives analysed (usually more than 50) and the Tn5-promoted transposition events did not show a strong sequence preference (de Lorenzo et al., 1990). The effect observed with monocopies of the $t f d$ modules is probably due to poor gene expression, or a low gene copy number, resulting in low enzyme activity, as was determined for chlorocatechol 1,2-dioxygenase (Table 3) and chloromuconate cycloisomerase (not shown). In this context, Pérez-Pantoja et al. (2000) have shown that the presence of multiple copies of each $t f d$ module allows strain JMP222 to grow on $3-\mathrm{CB}$ as a sole carbon source. When the $x y l S-$ $x y l X Y Z L$ gene module was introduced into strain JMP222 containing multiple copies of $t f d R-t f d C_{\mathrm{I}} D_{\mathrm{I}} E_{\mathrm{I}} F_{\mathrm{I}}$ or $t f d R-t f d D_{\mathrm{II}} C_{\mathrm{II}} E_{\mathrm{II}} F_{\mathrm{II}}$, the resulting derivatives, JMP222::X(pBBR1M-I) and JMP222::X(pBBR1M-II), respectively, could grow on $0.5-10 \mathrm{mM} 4-\mathrm{CB}$ (Fig. 2a) and on 3-CB (not shown). With regard to the growth of derivatives on $3-\mathrm{CB}$, derivatives containing the $t f d R-$ $t f d D_{\mathrm{II}} C_{\mathrm{II}} E_{\mathrm{II}} F_{\mathrm{II}}$ gene module were less efficient than those containing the $t f d R-t f d C_{\mathrm{I}} D_{\mathrm{I}} E_{\mathrm{I}} F_{\mathrm{I}}$ gene module (Pérez-Pantoja et al., 2000; this work). However, the differences between these two $t f d$ gene modules were less pronounced when the growth substrate was 4-CB (Fig. 2a). The explanation for this observation is that the main muconate produced by $3-\mathrm{CB}$ is 2 -chloromuconate (Pieper et al., 1993). This intermediate, which is poorly metabolized by the enzyme encoded by $t f d D_{\mathrm{I}}$, is an even worse substrate for the enzyme encoded by $t f d F_{\text {II }}$ (Laemmli et al., 2002; Pérez-Pantoja et al., 2000, Plumeier et al., 2002). In contrast, 3-chloromuconate or 2,4-dichloromuconate, the muconates produced during growth on 4-CB or 3,5-DCB, respectively, are good substrates for the chloromuconate cycloisomerases encoded by $t f d D_{\text {I }}$ and $t f d D_{\text {II }}$ (Kuhm et al., 1990; PérezPantoja et al., 2000; Pieper et al., 1993; Plumeier et al., 2002; Vollmer et al., 1999). 
These results indicate that a monocopy insertion of the tfd gene modules, alone or in combination, is not enough to support the growth of $R$. eutropha on substrates that produce 3-, 4- or 3,5-dichlorocatechol. This is consistent with two recent observations from our laboratory - (i) that a JMP134 derivative harbouring a chromosomal integration of pJP4 is unable to grow on $3-\mathrm{CB}$ and (ii) that the wild-type strain harbours five copies of pJP4 per genome (Trefault et al., 2002). The copy number of the $c l c$ genes and the $t c b$ genes, which encode chlorocatechol pathways similar to that encoded by the $t f d$ genes, has also been shown to be a limiting factor for growth of bacteria on chloroaromatic compounds (Klemba et al., 2000; Ravatn et al., 1998).

\section{The $t f d F_{11}$-encoded maleylacetate reductase plays a major role in the metabolism of 3,5-DCB in $R$. eutropha JMP134}

The experiments carried out to study the effect of the presence of multiple copies of the $t f d$ genes showed an additional difference between the two tfd gene modules. Strain JMP222::X(pBBR1M-I) was unable to grow on 3,5-DCB but strain JMP222::X(pBBR1M-II) was able to grow on this substrate, albeit at lower 3,5-DCB concentrations (Fig. 2b). Such behaviour may be due to the different maleylacetate reductase activities that the two tfd gene modules possess (Pérez-Pantoja et al., 2000; Plumeier et al., 2002). When strain JMP222(pBBR1M-II) is grown on 3-CB, it expresses about three times more maleylacetate reductase activity than strain JMP222(pBBR1M-I) (Plumeier et al., 2002). It is worth mentioning that maleylacetate reductase encoded on the chromosome of strain JMP134 is not expressed during growth on 2,4-D or 3-CB (Padilla et al., 2000; Plumeier et al., 2002). Therefore, it is improbable that the chromosomal maleylacetate reductase activity is expressed during growth of strain JMP134 on 4-CB or 3,5-DCB. No significant differences between the activity with maleylacetate and 2-chloromaleylacetate (the intermediates from mono- and dichlorinated substrates, respectively) have been reported for maleylacetate reductases (Padilla et al., 2000; PérezPantoja et al., 2000; Seibert et al., 1993). However, maleylacetate reductase is required twice during the metabolism of dichlorinated compounds, because it converts 2-chloromaleylacetate into maleylacetate, and maleylacetate into 3-oxoadipate (Fig. 1b). Therefore, if $\mathrm{TfdF}_{\mathrm{II}}$ is more active than $\mathrm{TfdF}_{\mathrm{I}}$, although the activity of these two proteins is not as different as initially reported (Pérez-Pantoja et al., 2000; Plumeier et al., 2002), its contribution to (chloro)maleylacetate turnover would be more important. Evidence for a significant role of $\mathrm{TfdF}_{\mathrm{II}}$ in the metabolism of 3,5-DCB came from the analysis of additional $R$. eutropha derivatives. When strain JMP222:: $\mathrm{X}$ harboured $\mathrm{pBBR} \Delta \mathrm{F}_{\mathrm{II}}$, a pBBR1M-IIderived plasmid lacking the $t f d F_{\mathrm{II}}$-encoded maleylacetate reductase gene, the ability of this strain to grow on 3,5-DCB was completely abolished (data not shown). In contrast, its ability to grow on 4-CB was still present, but the ability to grow on $4-\mathrm{CB}$ decreased to a similar
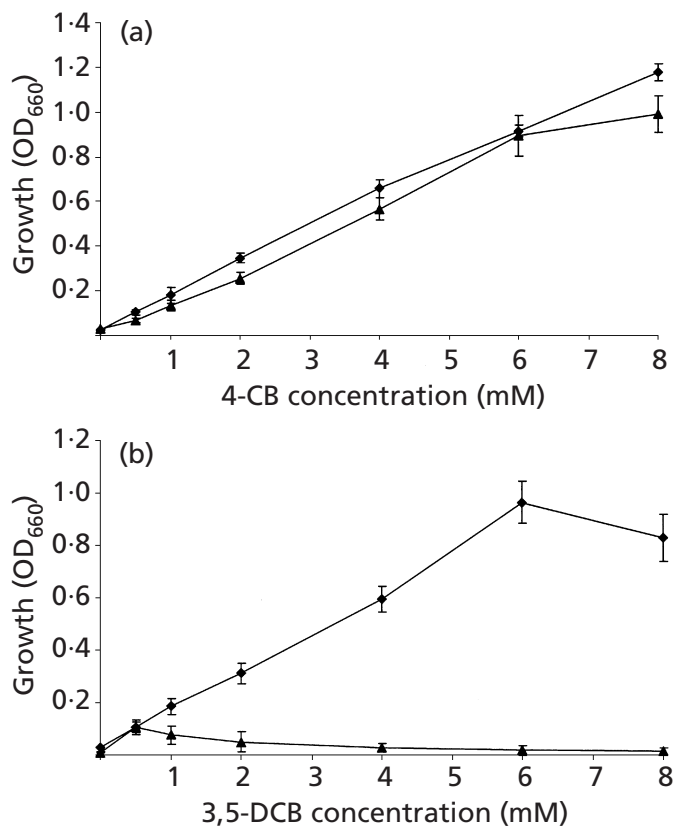

Fig. 3. Growth of $R$. eutropha derivatives containing different maleylacetate-reductase-encoding genes on CBs. Effects of the CB concentration on growth of $R$. eutropha JMP134::X ( $\diamond)$ and its derivative JMP134::X(pJP4 $\left.\Delta \mathrm{F}_{\|}\right)(\boldsymbol{\Delta})$, harbouring a $t f d F_{\|^{-}}$ inactivated pJP4, with (a) 4-CB or (b) 3,5-DCB. Samples were taken at the stationary phase of growth, usually after $48 \mathrm{~h}$ cultivation. Each point corresponds to the mean \pm SD of three independent experiments.

extent in strains JMP222:: $\mathrm{X}\left(\mathrm{pBBR} \Delta \mathrm{F}_{\mathrm{I}}\right)$ and JMP222:: $\mathrm{X}\left(\mathrm{pBBR} \Delta \mathrm{F}_{\mathrm{II}}\right)$ (data not shown). More significantly, when $t f d F_{\text {II }}$ was inactivated in pJP4 by the insertion of a gentamicin-resistance gene, the corresponding $R$. eutropha JMP134 derivative, JMP134:: $\mathrm{X}\left(\mathrm{pJP} 4 \Delta \mathrm{F}_{\mathrm{II}}\right)$, was unable to grow on 3,5-DCB, but still grew on 4-CB (Fig. 3). These observations strongly suggest that the presence of $\mathrm{TfdF}_{\mathrm{I}}$ and/or the chromosomal maleylacetate reductase is not enough to allow growth of $R$. eutropha JMP134 on 3,5-DCB.

\section{CONCLUSIONS}

The results of this work show that even though the acquisition of a new peripheral activity can actually enhance the catabolic abilities of R. eutropha JMP134, these new abilities are strongly influenced by the $t f d$ gene dosage. The results also show that some of these new properties, such as the unexpected use of 3,5-DCB as a growth substrate, depend on the presence of a putative chromosomal $x y l S$-like regulatory element, active in response to chlorinated benzoates, and on the differences in the activities of the maleylacetate reductases encoded by $t f d F_{\mathrm{I}}$ and $t f d F_{\mathrm{II}}$. The results reported here provide novel insights into understanding the outcome of the acquisition of genes encoding peripheral or central reactions, into the evolution of catabolic abilities toward chlorinated aromatic pollutants and, also, into pre- 
dicting the behaviour of strains engineered to contain catabolic genes.

\section{ACKNOWLEDGEMENTS}

This work was supported by grant 8990004 from FONDECYT-Chile and a collaborative grant from CONICYT, Chile, and BMBF-FZK/Karlsruhe. T.L. is a MECESUP Ph.D. fellow. D.P.-P. is a CONICYT Ph.D. fellow. We thank C. Harwood (Department of Microbiology, University of Iowa, Iowa City, IA 52242, USA) for providing pHRP316 and V. de Lorenzo (Centro Nacional de Biotecnología CSIC, Campus de Cantoblanco 28049, Madrid, Spain) for providing pSPM100.

\section{REFERENCES}

Ahmed, A. \& Podemski, L. (1995). The revised nucleotide sequence of Tn5. Gene 154, 129-133.

Alexeyev, M. F., Shokolenko, I. N. \& Croughan, T. P. (1995). New mini-Tn5 derivatives for insertion mutagenesis and genetic engineering in Gram-negative bacteria. Can J Microbiol 41, 1053-1055.

Ausubel, F. M., Brent, R., Kingston, R. E., Moore, D. D., Seidman, J. G., Smith, J. A. \& Struhl, K. (editors) (1992). Short Protocols in Molecular Biology, 2nd edn. New York: Greene Publishing Associates.

Bradford, M. M. (1976). A rapid and sensitive method for the quantitation of microgram quantities of protein utilizing the principle of protein-dye binding. Anal Biochem 72, 248-254.

Brinkmann, U. \& Reineke, W. (1992). Degradation of chlorotoluenes by in vivo constructed hybrid strains: problems of enzyme specificity, induction and prevention of meta-pathway. FEMS Microbiol Lett 75, 81-87.

Clément, P., Matus, V., Cárdenas, L. \& González, B. (1995). Degradation of trichlorophenols by Alcaligenes eutrophus JMP134. FEMS Microbiol Lett 127, 51-55.

Cowles, C. E., Nichols, N. N. \& Harwood, C. (2000). BenR, a XylS homologue, regulates three different pathways of aromatic acid degradation in Pseudomonas putida. J Bacteriol 182, 6339-6346.

de Lorenzo, V., Herrero, M., Jacubzik, U. \& Timmis, K. N. (1990). Mini-Tn5 transposon derivatives for insertion mutagenesis, promoter probing and chromosomal insertion of cloned DNA in Gram-negative eubacteria. J Bacteriol 172, 6568-6572.

Don, R. H. \& Pemberton, J. M. (1981). Properties of six pesticide degradation plasmids isolated from Alcaligenes paradoxus and Alcaligenes eutrophus. J Bacteriol 145, 681-686.

Don, R. H., Weightman, A. J., Knackmuss, H.-J. \& Timmis, K. N. (1985). Transposon mutagenesis and cloning analyses of the pathways for degradation of 2,4-dichlorophenoxyacetic acid and 3-chlorobenzoate in Alcaligenes eutrophus JMP134(pJP4). J Bacteriol 161, 85-90.

Friedrich, B., Meyer, M. \& Schlegel, H. G. (1983). Transfer and expression of the herbicide-degrading plasmid pJP4 in aerobic autotrophic bacteria. Arch Microbiol 134, 92-97.

Haugland, R. A., Schlemm, D. J., Lyons, R. P., III, Sferra, P. R. \& Chakrabarty, A. M. (1990). Degradation of the chlorinated phenoxyacetate herbicides 2,4-dichlorophenoxyacetic acid and 2,4,5-trichlorophenoxyacetic acid by pure and mixed bacterial cultures. Appl Environ Microbiol 56, 1357-1362.

Jeffrey, W. H., Cuskey, S. M., Chapman, P. J., Resnick, S. \& Olsen, R. H. (1992). Characterization of Pseudomonas putida mutants unable to catabolize benzoate: cloning and characterization of
Pseudomonas genes involved in benzoate catabolism and isolation of a chromosomal DNA fragment able to substitute for $x y l S$ in activation of the TOL lower-pathway promoter. J Bacteriol 174, 4986-4996.

Kasberg, T., Daubaras, D. L., Chakrabarty, A. M., Kinzelt, D. \& Reineke, W. (1995). Evidence that operons $t c b, t f d$ and $c l c$ encode maleylacetate reductase, the fourth enzyme of the modified ortho pathway. J Bacteriol 177, 3885-3889.

Kleinsteuber, S., Müller, R. H. \& Babel, W. (2001). Expression of the 2,4-D degradative pathway of pJP4 in an alkaliphilic, moderately halophilic soda lake isolate, Halomonas sp. EF43. Extremophiles 5, 375-384.

Klemba, M., Jakobs, B., Wittich, R.-M. \& Pieper, D. H. (2000). Chromosomal integration of $t c b$ chlorocatechol degradation pathways genes as a means of expanding the growth substrate range of bacteria to include haloaromatics. Appl Environ Microbiol 66, 3255-3261.

Kovach, M. E., Elzer, P. H., Hill, D. S., Robertson, G. T., Farris, M. A., Roop, R. M., 2nd \& Peterson, K. M. (1995). Four new derivatives of the broad-host-range cloning vector pBBR1MCS, carrying different antibiotic-resistance cassettes. Gene 166, 175176.

Kröckel, L. \& Focht, D. (1987). Construction of chlorobenzeneutilizing recombinants by progenitive manifestation of a rare event. Appl Environ Microbiol 53, 2470-2475.

Kuhm, A. E., Schlömann, M., Knackmuss, H.-J. \& Pieper, D. H. (1990). Purification and characterization of dichloromuconate cycloisomerase from Alcaligenes eutrophus JMP134. Biochem J 266, 877-883.

Laemmli, C. M., Leveau, J. H. J., Zehnder, A. J. B. \& van der Meer, J. R. (2000). Characterization of a second $t f d$ gene cluster for chlorophenol and chlorocatechol metabolism on plasmid pJP4 in Ralstonia eutropha JMP134(pJP4). J Bacteriol 182, 4165-4172.

Laemmli, C. M., Schönenberger, R., Suter, M., Zehnder, A. J. B. \& van der Meer, J. R. (2002). TfdDII, one of the two chloromuconate cycloisomerases of Ralstonia eutropha JMP134(pJP4), cannot efficiently convert 2-chloro-cis, cis-muconate to trans-dienelactone to allow growth on 3-chlorobenzoate. Arch Microbiol 178, $13-25$.

Leveau, J. H. J., König, F., Füchslin, H., Werlen, C. \& van der Meer, J. R. (1999). Dynamics of multigene expression during catabolic adaptation of Ralstonia eutropha JMP134(pJP4) to the herbicide 2,4-dichlorophenoxyacetate. Mol Microbiol 33, 396-406.

Matrubutham, U. \& Harker, A. H. (1994). Analysis of duplicated gene sequences associated with $t f d R$ and $t f d S$ in Alcaligenes eutrophus JMP134. J Bacteriol 176, 2348-2353.

Padilla, L., Matus, V., Zenteno, P. \& González, B. (2000). Degradation of 2,4,6-trichlorophenol via chlorohydroxyquinol in Ralstonia eutropha JMP134 and JMP222. J Basic Microbiol 40, 243-249.

Parales, R. E. \& Harwood, C. S. (1993). Construction and use of a new broad-host-range lac $\mathrm{Z}$ transcriptional fusion vector, pHRP309, for gram - bacteria. Gene 133, 23-30.

Pérez-Pantoja, D., Guzmán, L., Manzano, M., Pieper, D. H. \& González, B. (2000). Role of $t f d C_{\mathrm{I}} D_{\mathrm{I}} E_{\mathrm{I}} F_{\mathrm{I}}$ and $t f d D_{\mathrm{II}} C_{\mathrm{II}} E_{\mathrm{II}} F_{\mathrm{II}}$ gene modules in catabolism of 3-chlorobenzoate by Ralstonia eutropha JMP134(pJP4). Appl Environ Microbiol 66, 1602-1608.

Perkins, E. J., Gordon, M. P., Cáceres, O. \& Lurquin, P. F. (1990). Organization and sequence analysis of the 2,4-dichlorophenol hydroxylase and dichlorocatechol oxidative operons of plasmid pJP4. J Bacteriol 172, 2352-2359.

Pieper, D. H., Reineke, W., Engesser, K.-H. \& Knackmuss, H.-J. 
(1988). Metabolism of 2,4-dichlorophenoxyacetic acid, 4-chloro2-methylphenoxyacetic acid and 2-methylphenoxyacetic acid by Alcaligenes eutrophus JMP134. Arch Microbiol 150, 95-102.

Pieper, D. H., Engesser, K.-H. \& Knackmuss, H.-J. (1989). Regulation of catabolic pathways of phenoxyacetic acids and phenols in Alcaligenes eutrophus JMP134. Arch Microbiol 151, 356-371.

Pieper, D. H., Knackmuss, H.-J. \& Timmis, K. N. (1993). Accumulation of 2-chloromuconate during metabolism of 3-chlorobenzoate by Alcaligenes eutrophus JMP134. Appl Microbiol Biotechnol 39, 563-567.

Plumeier, I., Pérez-Pantoja, D., Heim, S., González, B. \& Pieper, D. H. (2002). Importance of different $t f d$ genes for degradation of chloroaromatics by Ralstonia eutropha JMP134. J Bacteriol 184, 4054-4064.

Ramos, J. L., Stolz, A., Reineke, W. \& Timmis, K. N. (1986). Altered effector specificities in regulators of gene expression: TOL plasmid $x y l S$ mutants and their use to engineer expansion of the range of aromatics degraded by bacteria. Proc Natl Acad Sci US A 83, 8467-8471.

Ravatn, R., Studer, S., Springael, D., Zehnder, A. J. B. \& van der Meer, J. R. (1998). Chromosomal integration, tandem amplification, and deamplification in Pseudomonas putida F1, of a 105kilobase genetic element containing the chlorocatechol degradative genes from Pseudomonas sp. strain B13. J Bacteriol 180, 4360-4369.

Reineke, W. (1998). Development of hybrid strains for the mineralization of chloroaromatics by patchwork assembly. Annu Rev Microbiol 52, 287-331.

Reineke, W. \& Knackmuss, H.-J. (1978). Chemical structure and biodegradability of halogenated aromatic compounds. Substituent effects on 1,2-dioxygenation of benzoic acid. Biochim Biophys Acta 542, 412-433.

Reineke, W. \& Knackmuss, H.-J. (1979). Construction of haloaromatics utilising bacteria. Nature 277, 385-386.
Reineke, W. \& Knackmuss, H.-J. (1980). Hybrid pathway to chlorobenzoate metabolism in Pseudomonas sp. B13 derivatives. J Bacteriol 142, 467-473.

Reineke, W. \& Knackmuss, H.-J. (1988). Microbial degradation of haloaromatics. Annu Rev Microbiol 42, 263-287.

Rojo, F., Pieper, D. H., Engesser, K.-H., Knackmuss, H.-J. \& Timmis, K. N. (1987). Assemblage of ortho cleavage route for simultaneous degradation of chloro- and methylaromatics. Science 238, 13951398.

Sahasrabudhe, A. V. \& Modi, V. V. (1991). Degradation of isomeric monochlorobenzoates and 2,4-dichlorophenoxyacetic acid by a constructed Pseudomonas sp. Appl Microbiol Biotechnol 34, 556-557.

Seibert, V., Stadler-Fritzsche, K. \& Schlömann, M. (1993). Purification and characterization of maleylacetate reductase from Alcaligenes eutrophus JMP134(pJP4). J Bacteriol 175, 6745-6754.

Streber, W., Timmis, K. N. \& Zenk, M. H. (1987). Analysis, cloning and high-level expression of 2,4-dichlorophenoxyacetate monooxygenase gene tfdA of Alcaligenes eutrophus JMP134. J Bacteriol 169, 2950-2955.

Trefault, N., Clément, P., Manzano, M., Pieper, D. H. \& González, B. (2002). The copy number of the catabolic plasmid pJP4 affects growth of Ralstonia eutropha JMP134(pJP4) on 3-chlorobenzoate. FEMS Microbiol Lett 212, 95-100.

van der Meer, J. R, de Vos, W., Harayama, S. \& Zehnder, A. J. B. (1992). Molecular mechanisms of genetic adaptation to xenobiotic compounds. Microbiol Rev 56, 677-694.

Vollmer, M. D., Schell, U., Seibert, V., Lakner, S. \& Schlömann, M. (1999). Substrate specificities of the chloromuconate cycloisomerases from Pseudomonas sp. B13, Ralstonia eutropha JMP134 and Pseudomonas sp. P51. Appl Microbiol Biotechnol 51, 598-605.

Received 12 April 2002; revised 17 June 2002; accepted 16 July 2002. 